\title{
Bio-efficacy of Chemical Insecticides and Biopesticides against Gram Pod Borer, Helicoverpa armigera (Hubner) and Spotted Pod Borer, Maruca testulalis (Geyer) on Greengram, [Vigna radiata (L.) Wilczek]
}

V.P. Meena, S.K. Khinchi, D.K. Bairwa, Akhter Hussain, K.C. Kumawat, K. Anvesh

$10.18805 / L R-4416$

\begin{abstract}
Background: Gram pod borer, Helicoverpa armigera (Hubner) and spotted pod borer, Maruca testulalis (Geyer) are important pod boring insects infesting the greengram, [Vigna radiata (L.) Wilczek] throughout the India. A number of synthetic insecticides are known to be effective against these borers but most of them have been phased out as a result of high toxicity to the pollinators and other biotic fauna, therefore, a group of new chemical insecticides with biopesticides have been tested for bioefficacy against these insect pests.

Method: A field experiment was conducted at S.K.N. College of Agriculture, Jobner, Rajasthan during kharif, 2018 in randomized block design (RBD) with 9 treatments and 3 replications. The observations were recorded of Helicoverpa armigera (Hubner) and spotted pod borer, Maruca testulalis (Geyer) borers one day before and 1, 3, 7 and 15 days after application of insecticides and biopesticides in each the spray from ten randomly selected and tagged plants/ plot. From the data recorded per cent reduction in population over control was calculated. The per cent pod damage was calculated by counting damaged pods out of healthy pods of greengram.

Result: The spinosad 45 SC $(0.01 \%)$ proved to be most effective, indoxacarb 14.5 SC $(0.01 \%)$ followed by fipronil 5 SC (0.01\%), whereas, treatments of neem leaf extract $(10.00 \%)$, Beauveria bassiana 1.15 WP 1 X10 $10^{8}$ spore/ I proved to be least effective. The maximum seed yield of $9.13 \mathrm{q} \mathrm{ha}^{-1}$ was obtained in the plots treated with spinosad $45 \mathrm{SC}(0.01 \%)$ followed by indoxacarb $14.5 \mathrm{SC}$ $(0.01 \%)\left(8.89 \mathrm{q} \mathrm{ha}^{-1}\right)$, fipronil 5 SC $(0.01 \%)\left(8.60 \mathrm{q} \mathrm{ha}^{-1}\right)$.
\end{abstract}

Key words: Bio-efficacy, Greengram, Helicoverpa armigera, Insecticides, Maruca testulalis.

\section{INTRODUCTION}

Greengram [Vigna radiata (L.) Wilczek] (family: Leguminosae) is one of the most important Kharifpulse crop grown in India. It is cultivated across seasons in different environments and in variable soil conditions in the South and South-East Asia, Africa, South America and Australia (Parihar et al., 2017). It is one of the most widely cultivated pulse crop after chickpea and pigeonpea (Swaminathan et al., 2012). In India, during 2018-19 the total area and production of pulses is 29.03 million hectares, 23.39 million tonnes but greengram occupied 47.56 thousand hectares, 2339.75 thousand tonnes (Anonymous, 2019). The major producing states in India being Andhra Pradesh, Orissa, Maharashtra, Madhya Pradesh and Rajasthan accounting for about 70 per cent of total production.

About 65 species of insects has been recorded on greengram (Siddapaji et al., 1979). The insect pests exercising heavy toll of greengram crop include pod borer complex viz, gram pod borer, Helicoverpa armigera (Hubner), blue butter fly, Lampides boeticus L., spotted pod borer, Maruca testulalis (Geyer), pod bug, Riptortus spp. are major pests of greengram (Sundararajan and Chitra 2017). Gram pod borer, $H$. armigera is widely distributed throughout India and has been recorded feeding on 181
Department of Entomology, S.K.N. College of Agriculture, Sri Karan Narendra Agriculture University, Jobner-303 329, Rajasthan, India.

Corresponding Author: V.P. Meena, Department of Entomology, S.K.N. College of Agriculture, Sri Karan Narendra Agriculture University, Jobner-303 329, Rajasthan, India.

Email: vijaypalmeena16@gmail.com

How to cite this article: Meena, V.P., Khinchi, S.K., Bairwa, D.K., Hussain, A., Kumawat, K.C. and Anvesh, K. (2021). Bio-efficacy of Chemical Insecticides and Biopesticides against Gram Pod Borer, Helicoverpa armigera (Hubner) and Spotted Pod Borer, Maruca testulalis (Geyer) on Green gram, [Vigna radiata (L.) Wilczek]. Legume Research. DOI: 10.18805/LR-4416.

Submitted: 11-05-2020 Accepted: 05-06-2021 Online: 06-09-2021

cultivated and uncultivated plant species belonging to 45 families (Manjunath et al., 1989). Sixty cultivated and sixtyseven wild host plants attacked by $H$. armigera have been recorded from India (Karim, 2000). Spotted pod borer, $M$. testulalis attributed to the regular outbreaks of greengram because of its extensive host range and destructiveness; it became a persistent pest in greengram. It is reported that 20-30 per cent pod damage in greengram is caused due to spotted pod borer (Zahid et al., 2008). 
It is a common observation that the population of pod borers is brought down by the application of chemical insecticides and botanicals. The present study is an attempt at chemical insecticides and biopesticides were evaluated against pod borer complex with seed yield of greengram as well as at decipher the economics of different treatments.

\section{MATERIAL AND METHODS}

The present investigation was conducted at Agronomy Farm, S.K.N. College of Agriculture, Jobner, Rajasthan, India during kharif, 2018. The fertilizers and other cultural practices were followed as per the recommendations in the package of practices of Rajasthan. The experiment was laid out in a simple randomized block design (RBD) with nine treatments and each treatment replicated thrice. The individual plot size was $3.0 \mathrm{~m} \times 2.5 \mathrm{~m}$, keeping row to row and plant to plant distance of $30 \mathrm{~cm}$ and $10 \mathrm{~cm}$, respectively. The seeds of greengram variety, IPM-02-03 were sown on first week of July.

\section{Method of observation}

The observations on larval populations of gram pod borer, $H$. armigera and spotted pod borer, $M$. testulalis were recorded from their appearance to harvesting of the greengram crop. For this purpose, ten plants were randomly selected from each plot and tagged. The incidence of $H$. armigera and $M$. testulalis was determined by counting the population of larvae on ten randomly selected tagged plants at weekly interval. The observations on pod borers population were recorded regularly one day before and 1 , 3, 7 and 15 days after application of insecticides and biopesticides in both the sprays. The incidence was also studied in terms of mean pod damage by counting the total number of pods and damage pods on ten randomly selected tagged plants and mean damage was calculated by using the following formula:

The infestation was expressed as a percentage:

$$
\text { Mean pod infestation }(\%)=\frac{\text { No. of infested pods }}{\text { No. of total pods }} \times 100
$$

\section{Interpretation of data}

The population data thus recorded was converted to per cent reduction in population using the method utilized by Henderson and Tilton (1955). The statistical analysis (analysis of variance) was carried out by transforming the data of per cent reduction into angular transformation values (Gomez and Gomez, 1976). The data of seed yield influenced as a result of application of different treatments were also subjected to analysis of variance.

The avoidable loss and increase in seed yield over control was calculated for each treatment by the following formula.

$$
\% \text { avoidable loss }=\frac{\begin{array}{l}
\text { Highest yield } \\
\text { in treated plot }-\begin{array}{c}
\text { Yield in the } \\
\text { untreated }
\end{array}
\end{array}}{\text { Highest yield in treated plot }} \times 100
$$

$\%$ increase in yield $=\frac{\begin{array}{c}\text { Yield in } \\ \text { treated plot }- \text { Yield in } \\ \text { control }\end{array}}{\text { Yield in control }} \times 100$

These formulae do not give the exact losses/ increase in yield because even in the best treatment some damage occurs. However, this is considered to be the most feasible method (Pradhan, 1964). The economics of each treatment was worked out by computing the cost of insecticides as well as their cost of application. The gross income was worked out by multiplying the yield with the whole sale rate of greengram seed prevailing at the time of threshing.

\section{RESULTS AND DISCUSSION}

The bioefficacy of different treatments were evaluated on the basis of per cent reduction of pod borers population on greengram.

\section{First spray of insecticides and biopesticides}

The pre treatment population of pod borer recorded ranged between 8 to 11 larvae for gram Pod borer, $H$. armigera and 13 to 17 larvae for spotted pod borer, M. testulalis. One day after application of treatments (Table 1), it was observed that all the treatments were found significantly superior over the untreated control. However, their existed a considerable difference in between the different insecticidal treatments. Maximum per cent reduction of $H$. armigera and $M$. testulalis population after three days of insecticidal application was recorded in all treatment and it ranged from 33.54 to 73.42 per cent reduction in pod borer population and proved significantly superior over control. The maximum reduction 73.42 per cent recorded in spinosad 0.01 per cent treated plots. Agale et al. (2021) reported that spinosad 45 SC was most effective against $H$. armigera in pigeonpea. The next effective treatment was indoxacarb 0.01 per cent (71.39 per cent reduction) followed by fipronil 0.01 per cent (70.12 per cent reduction) which were at par with each other. The present findings are in agreement with that of Umbarkar and Parsana (2014) who reported that the spinosad 45 SC and indoxacarb 14.5 SC was the most effective and NSKE 10 per cent moderately effective insecticide in suppression of $M$. testulalis population on greengram. The Ha NPV $1 \mathrm{ml}$ I reduction with 66.67 per cent reduction, azadirachtin $5 \mathrm{ml} /$ I with 61.53 per cent reduction, NSKE 10.00 per cent with 60.13 per cent reduction, neem oil 1.00 per cent with 55.94 per cent reduction and were at par with each other. Yadav et al. (2015) reported that novaluron, difllubenzuron, NSKE and Metarrhizium anisopliae were least effective against sucking insect pests in clusterbean. Turkhade et al. (2014) reported that the treatment azadirachtin 300 ppm @ 5ml/ I is moderately effective against $H$. armigera.

After seven days of application, all the treatments proved significantly superior in reducing the population of gram pod borer and spotted pod borer in the field. The maximum reduction 70.25 per cent was recorded in the treatment of spinosad 0.01 per cent. The next effective 


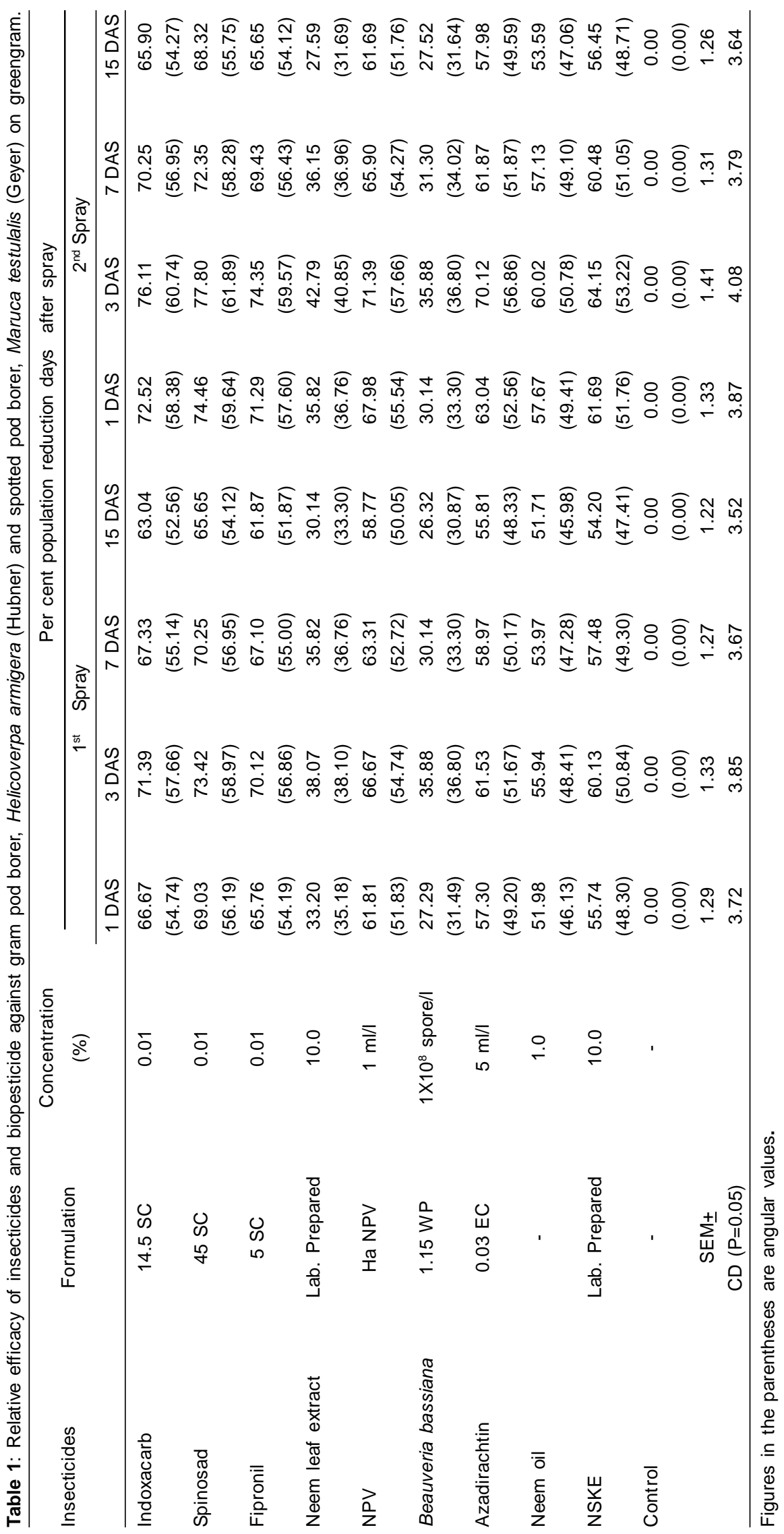


treatment was indoxacarb 0.01 per cent with 67.33 per cent reduction and fipronil 0.01 per cent with 67.10 per cent reduction followed by $\mathrm{Ha}$ NPV $1 \mathrm{ml} / \mathrm{I}$ with 63.31 per cent reduction, azadirachtin $5 \mathrm{ml}$ I with 58.97 per cent reduction, NSKE 10.00 per cent with 57.48 per cent reduction and neem oil 1.00 per cent with 53.97 per cent reduction, which were at par with each other. Kaushik et al. (2016). Mittal and Ujagir (2005) reported that spinosad is most effective treatment in reducing $M$. testulalis population. Srihari and Patnaik (2006) found that the indoxacarb, spinosad gave the greatest reduction in larval population of $M$. testulalis. The neem leaf extract 10.00 per cent was recorded with 35.82 per cent reduction, $B$. bassiana $1 \mathrm{~g} / \mathrm{I}$ with 30.14 per cent reduction and were at par with each other.

After fifteen days, maximum reduction in gram pod borer and spotted pod borer was found in spinosad 0.01 per cent treated plots (65.65 per cent reduction) followed by indoxacard 0.01 per cent (63.04 per cent reduction) and fipronil 0.01 per cent (61.87 per cent). Dabariya et al. (2010) reported that indoxacard 0.0075 per cent gave highest per cent mortality of $H$. armigera followed by spinosad 0.009 per cent, profenophos + cypermethrin 0.044 per cent and endosulfan 0.07 per cent in pigeonpea. The next effective treatments were $\mathrm{Ha}$ NPV $1 \mathrm{ml}$ I with 58.77 per cent reduction, azadirachtin $5 \mathrm{ml} / \mathrm{I}$ with 58.81 per cent reduction, NSKE 10.00 per cent with 54.20 per cent reduction, neem oil 1.00 per cent was 51.71 per cent reduction and all were at par with each other. The findings are in close agreement with Padmanaban and Arora (2002) who reported 3 sprays at weekly interval of $\mathrm{Ha}$ NPV 375 LEha-1 significantly lower larval population of 0.83 / ten plants. Jayaraj et al. (1987) reported 5 sprays of 250 LE $H a$ NPV at weekly intervals gave satisfactory results against $H$. armigera. Similar results was noticed by Gopali (1998). Deshmukh et al. (2010) found that flubendiamide 0.007 per cent was most effective in reducing the $H$. armigera population and pod damage in pigeonpea.

\section{Second spray of insecticides and biopesticides}

The maximum reduction of 74.46 per cent was recorded after one day in spinosad 0.01 per cent followed by indoxocarb 0.01 per cent and fipronil 0.01 per cent i.e. 72.52 per cent, 71.29 per cent reduction, respectively. The next effective treatments were Ha NPV $1 \mathrm{ml} / \mathrm{l}$, azadirachtin $5 \mathrm{ml} /$ I, NSKE 10.00 per cent, neem oil 1.00 per cent with 67.98 , $63.04,61.69$ and 57.67 per cent reduction respectively, which were at par with each other. The minimum reduction was recorded in plots treated with neem leaf extract 10.00 per cent was 35.82 per cent reduction and $B$. bassiana $1 \mathrm{~g} /$ I was 30.14 per cent reduction which was inferior to all the other insecticidal treatments. All the treatments significantly reduced the gram pod borer and spotted pod borer damage after three days of treatment and the per cent reduction ranged from 37.93 to 77.80 per cent. The maximum reduction of pod damage after three days of spraying with recorded in the plots treated with spinosad 0.01 per cent

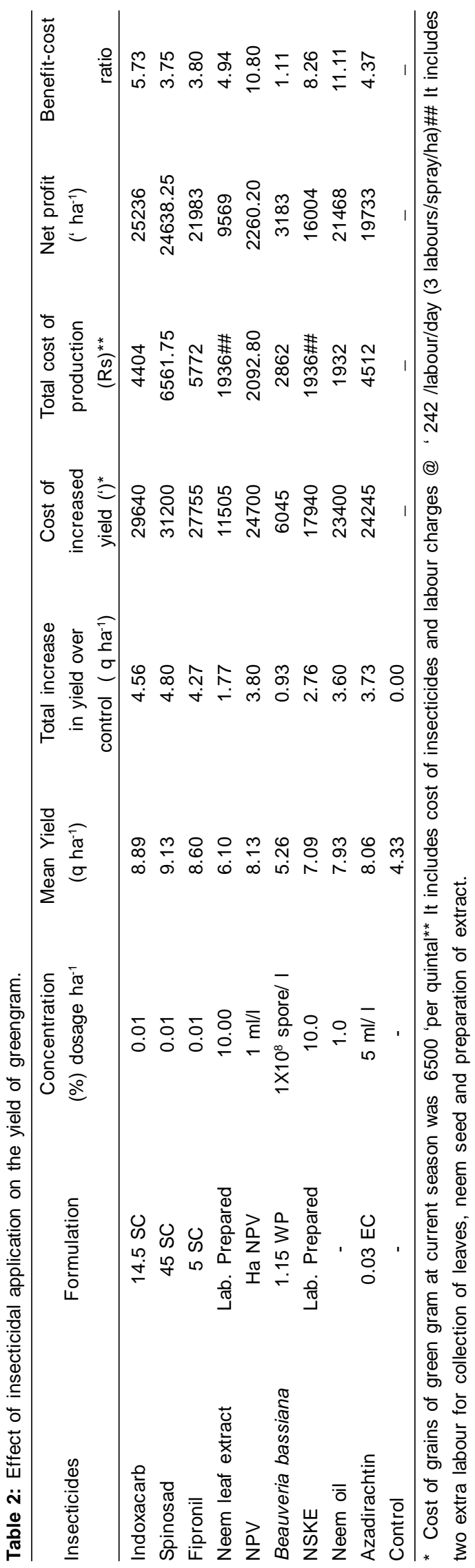

Legume Research- An International Journal 
Bio-efficacy of Chemical Insecticides and Biopesticides against Gram Pod Borer, Helicoverpa armigera (Hubner) and Spotted ...

Table 3: Comparative economics of insecticidal treatment on greengram.

\begin{tabular}{|c|c|c|c|}
\hline Insecticides & Formulation & Concentration (\%) dosage ha-1 & Mean Yield $\left(\mathrm{q} \mathrm{ha}^{-1}\right)$ \\
\hline Indoxacarb & $14.5 \mathrm{SC}$ & 0.01 & 8.89 \\
\hline Spinosad & $45 \mathrm{SC}$ & 0.01 & 9.13 \\
\hline Fipronil & $5 \mathrm{SC}$ & 0.01 & 8.60 \\
\hline Neem leaf extract & Lab. Prepared & 10.0 & 6.10 \\
\hline NPV & Ha NPV & $1 \mathrm{ml} / \mathrm{l}$ & 8.13 \\
\hline Beauveria bassiana & $1.15 \mathrm{WP}$ & $1 \times 10^{8}$ spore/ I & 5.26 \\
\hline NSKE & Lab. Prepared & 10.0 & 7.09 \\
\hline Neem oil & - & 1.0 & 7.93 \\
\hline Azadirachtin & $0.03 \mathrm{EC}$ & $5 \mathrm{ml} / \mathrm{l}$ & 8.06 \\
\hline Control & - & - & 4.33 \\
\hline S. $E m \pm C D(p=0.05)$ & & & 0.290 .86 \\
\hline
\end{tabular}

was 77.80 per cent reduction and followed by indoxacarb 0.01 per cent and fipronil 0.01 per cent with 72.52 and 71.29 per cent reduction respectively. The next effective treatments were $\mathrm{Ha}$ NPV $1 \mathrm{ml} / \mathrm{l}$, azadirachtin $5 \mathrm{ml} / \mathrm{l}$, NSKE 10.00 per cent, neem oil 1.00 per cent was $71.39,70.12,64.15$ and 60.02 per cent reduction respectively, which were at par with each other. The minimum reduction of 42.79 and 35.88 per cent was recorded in plots treated with neem leaf extract 10.00 per cent and $B$. bassiana $1 \mathrm{~g} / \mathrm{I}$ which were inferior to all the other insecticidal treatments. The per cent reduction after seven and fifteen days of application of treatments with the similar trend and proved significantly superior over control. Singh et al. (2014) revealed that Indoxacarb 14.5 SC was effective for $H$. armigera management. Yadav et al. (2015) also showed that Indoxacarb 14.5 SC was most effective in reducing the pod borer damage and approximately similar results were found by Sonune et al. (2010), Daharia and Katlam (2013) and Gadhiya et al. (2014).

\section{Effect of insecticides and biopesticides on the seed yield of greengram}

The data presented in the (Table 2) revealed that all the plots treated with insecticides and biopesticides gave significantly higher seed yield over control (4.33 $\left.\mathrm{q} \mathrm{ha}^{-1}\right)$. The maximum seed yield of $9.13 \mathrm{q} \mathrm{ha}^{-1}$ was obtained in the plots treated with spinosad $45 \mathrm{SC}$ followed by indoxacarb 14.5 SC (8.89 q ha-1) and fipronil 5 SC (8.60 q ha-1) which were found statistically at par with each other. The seed yield (8.13 $\mathrm{q} \mathrm{ha} \mathrm{h}^{-1}$ ) obtained in the treatment of Ha NPV which was at par with treatment of azadirachtin $0.03 \mathrm{EC}\left(8.06 \mathrm{q} \mathrm{ha}^{-1}\right)$, followed by the treatment NSKE 10.00 per cent with seed yield $\left(7.93 \mathrm{q} \mathrm{ha}^{-1}\right)$. The minimum seed yield of $\left(5.26 \mathrm{q} \mathrm{ha}^{-1}\right)$ was obtained in the plots treated with $B$. bassiana 1.15 WP followed by the treatment neem leaf extract $\left(6.10 \mathrm{q} \mathrm{ha}^{-1}\right)$ which was found statistically at par with each other. Jat et al. (2012), Chandel et al. (2014), Sharma et al. (2014) reported that the highest yield was recorded in spinosad 0.01 per cent followed by indoxacarb 0.01 per cent plot.

\section{Economics of insecticides and biopesticides}

The highest benefit cost ratio was obtained from the plot treated with Neem oil 1.0 per cent (11.11:1), followed by
NPV 1 m/l (10.80:1), NSKE (8.26:1), indoxacarb 0.01 per cent (5.73:1), neem leaf extract $(4.94: 1)$, azadirachtin (4.37:1), fipronil 0.01 per cent $(3.80: 1)$, spinosad 0.01 per cent $(3.75: 1)$ these treatment were proved to be most economic (Table 3). The lowest benefit cost ratio was computed in the plot treated with $B$. basssiana (1.11:1). The findings get full support from Gautam et al. (2018) who reported maximum benefit cost ratio in neem oil $5 \mathrm{ml} / \mathrm{I}$ and followed by NSKE.

\section{CONCLUSION}

Out of nine treatments evaluated against gram pod borer, $H$. armigera and spotted pod borer, $M$. testulalis. The spinosad 45 SC $(0.01 \%)$ proved to be most effective, indoxacarb 14.5 SC $(0.01 \%)$ followed by fipronil 5 SC $(0.01 \%)$, whereas, treatments of neem leaf extract $(10.00 \%)$, Beauveria bassiana 1.15 WP $1 \times 10^{8}$ spore/ I proved to be least effective. The maximum seed yield of $9.13 \mathrm{q} \mathrm{ha}^{-1}$ was obtained in the plots treated with spinosad 45 SC $(0.01 \%)$ followed by indoxacarb $14.5 \mathrm{SC}(0.01 \%)\left(8.89 \mathrm{q} \mathrm{ha}^{-1}\right)$, fipronil 5 SC $(0.01 \%)\left(8.60 \mathrm{q} \mathrm{ha}^{-1}\right)$. The highest benefit cost ratio was obtained from the plot treated with Neem oil 1.00 per cent (11.11), followed by Ha NPV $1 \mathrm{~m} / \mathrm{I}$ (10.80), NSKE (8.26), indoxacarb 0.01 per cent (5.73), neem leaf extract (4.94), azadirachtin (4.37), fipronil 0.01 per cent (3.80) and spinosad 0.01 per cent (3.75).

\section{REFERENCES}

Agale, S.V., Gupta Rajeev, Rangarao, G.V. and Wani, S.P. (2021). Efficacy of some biopesticides against Helicoverpa armigera (Hubner) in pigeonpea under natural condition, Legume Research. 44: 463-471.

Anonymous (2018-19). Department of Agriculture, Cooperation and Farmer Welfare. Directorate of Economic and Statistics. Ministry of Agriculture and Farmer Welfare. Government of India, Agriculture statistics at a Glance. 2018.

Chandel, S.F., Singh, P.K. and Ahmad, R. (2014). Population dynamics of Helicoverpa armigera (Hubner) and Campoletis chloridae on different crops. Annals of Plant Protection Science. 13: 379-383. 
Dabariya, P.M., Kabaria, B.B., Patel, V.N. and Joshi, M.D. (2010). Chemical control of gram pod borer, Helicoverpa armigera Hub. Infesting pigeonpea. Legume Research. 33: 224-226.

Daharia, S.K. and Katlam, B.P. (2013). Relative efficacy of newer insecticides against linseed bud fly, Dasyneuralini Barnes, The Bioscan. 8: 1079-1081.

Deshmukh, S.G., Sureja, B.V., Jethva, D.M. and Chatar, V.P. (2010). Field efficacy of different insecticides against Helicoverpa armigera (Hubner) infesting chickpea. Legume Research. 33: 269-273.

Gadhiya, H.A., Borad, P.K. and Bhut, J.B. (2014). Effectivness of synthetic insecticides against Helicoverpa armigera (Hubner) Hardwick and Spodoptera litura (Fabricius) infesting groundnut. The Bioscan. 9: 23-26.

Gautam, M.P., Chandra, U., Singh, S.N., Yadav, S.K. and Giri, S.K. (2018). Studies on Efficacy of Botanicals against Helicoverpa armigera (Hubner) on Chickpea Cicer arietinum (L.). International Journal Current Microbiology and Applied Science. 7: 612-618.

Gomez, K.A. and Gomez, A.A. (1976). Problem data. Statistical Procedure for Agricultural Rresearch (II ed.), John Wiley and Sons. New York. pp. 272-315.

Sonune, V.R., Bharodia, R.K., Jethva, D.M., Rathod, R.T. and Deshmukh, S.G. (2010). Field efficacy of chemical insecticides against spotted pod Borer, maruca vitrata (fabricius) infesting blackgram. Legume Research. 33(4): 287-290.

Gopali, J.B. (1998). Integrated management of pigeonpea pod borer, Helicoverpa armigera (Hubner) with special reference to $\mathrm{Ha}$ NPV and insectivorous birds. Ph.D. thesis, University of Agricultural Sciences, Dharwad, India.

Henderson, C.F. and Tilton, E.W. (1955). Test with acaricides against the brow wheat mite. Journal of Economic Entomology, 48: 157-161.

Jat, G.C., Agrawal, V.K., Tetarwal, A.S. and Yadav, P.C. (2012). Bio-efficacy of newer insecticides molecules against pod borer complex of indian bean, Lablab purpureus (L.) Sweet. Indian Journal of Applied Entomology, 26: 32-35.

Jayaraj, S., Rabindra, R.J. and Santharam, G. (1987). Control of Heliothis armigera (Hubner) on chickpea and lablab beans by nuclear polyhedrosis virus. Indian Journal of Agricultural Sciences. 57: 738-741.

Karim, S. (2000). Management of Helicoverpa armigera. Pakistan Journal of Biological Science. 3: 1213-1222.

Kaushik, A.K., Yadav, S.K. and Srivastava, P. (2016). Field efficacy of insecticides and mixture against spotted pod borer on cowpea. Annals of Plant Protection Science. 24: 89-92.

Manjunath, T.M., Bhatnagar, V.S., Panwar, C.S. and Sithananthan S. (1989). Economic Importance of $H$. armigera in india and assessment of their natural enemies and host plant. pp 197-228.
Mittal, V. and Ujagir, R. (2005). Evaluation of naturalyte spinosad against pod borer complex in early pigeonpea. Indian Journal of Plant Protection, 33: 211-215.

Padmanaban, N. and Arora, R. (2002). Field evaluation of native nucleopolyhedrovirus for the management of tomato fruit borer, Helicoverpa armigera (Hubner). Pesticide Research Journal. 14: 113-119.

Parihar, A.K., Basandrai, A.K., Sirari, A., Dinakaran, D., Singh, D., Kannan, K. (2017). Assessment of mungbean genotypes for durable resistance to Yellow Mosaic Disease: Genotype $\times$ Environment interactions. Plant Breed. 36: 94-100. Doi: 10.1111/pbr.12446.

Pradhan, S. (1964). Assessment of losses by insect pests of crops and estimation of insect population. Entomology in India. Entomological society of India, New Delhi, pp. 17-58.

Sharma, S., Nanda, K. and Nema, K.K. (2014). Chemical control of $H$. amrigera in chick pea. Annals of Plant Protection Science. 22: 85-87.

Siddapaji, C., Gowda, N.G. and Rao, G.N.G. (1979). Millipede-a new enemy of moong crop. Current Research. 8(7): 114-116.

Singh, A., Ali, S. and Gupta, P.K. (2014). Bio-efficacy of insecticides against Gram Pod Borer, Helicoverpa armigera (Hubner.) in chickpea. Annals of Plant Protection Sciences. 22: 257-259.

Soundararajan, R.P. and Chitra, N. (2017). Field evaluation of mungbean Vigna radiata L. germplasm for resistance against pod borer complex. Legume Research. 40: 768-772.

Srihari, B. and Patnaik, N.C. (2006). Use of new insecticides against Maruca vitrata (Geyer) in black gram. Annals of Biological Control. 22: 69-172.

Swaminathan, R., Singh, K. and Nepalia, V. (2012). Insect pests of greengram [Vigna radiata (L.) Wilczek] and their management. Agricultural Science. Godwin Aflakpui (Ed.), Tech Publications, Croatia, pp.197-222.

Turkhade, P.D., Gurve, S.S. and Nehare, S. (2014). Evaluation of new insecticides against chickpea pod borer Helicoverpa armigera (Hubner). Indian Journal of Applied Entomology. 28: 122-124.

Umbarkar, P.S. and Parsana, G.J. (2014). Field efficacy of different insecticides against spotted pod borer Maruca vitrata Geyer infesting green gram. Journal of Industrial Pollution Control. 30: 227-230.

Yadav, S.K., Agnihotri, M. and Bisht, R.S. (2015). Efficacy of insecticides and bio-pesticides against defoliators and spotted pod borer, Maruca vitrata in Black gram. Annals Plant Protection Science. 23: 65-68.

Yadav, S.R., Kumawat, K.C. and Khinchi, S.K. (2015). Efficacy of new insecticide molecules and bioagents against sucking insect pests of cluster bean, Cyamopsis tetragonoloba (Linn.) Taub. Legume Research. 38: 407-410.

Zahid, M.A., Islam, M.M., Begum, M.R. (2008). Determination of economic injury levels of Maruca vitrata in Greengram. Journal of Agricultural Rural Development. 6: 91-97. 